\section{Rebuilding the University of Liberia in the Midst of War}

\section{Patrick L. N. Seyon}

Patrick L. N. Seyon is the former president of the University of Liberia. Address: 49 Summer St., Arlington MA 02 174, USA.

$I^{2}$ arrived in Monrovia in March 1991—after nearly eight years of exile in the United States-and was shocked by the destruction of the University of Liberia-the country's only national institution of higher learning. In July 1990, the campus became the battlefield for opposing forces of Charles Taylor's National Patriotic Front of Liberia and Liberia's military dictator-Samuel K. Doe-for control of the city. The combatants seemed determined to destroy not just Liberia, but also its mind and soul—as embedded in and symbolized by the university.

Established in 1862 as Liberia College, the University of Liberia-the oldest degree-granting institution in West Africa-has trained leaders of state, church, industry, and commerce for Liberia and other African countries. During Africa's colonial period, the university provided higher education for many Africans for whom such education was unavailable in the colonies, and continued during postcolonial times.

\section{Could the university function-suppos- edly "educating students"-while clos- ing its eyes to the sociopolitical disorders in the society, because to do otherwise was to become "political"?}

Deteriorating socioeconomic and political conditions in Liberia in the late 1970s and early 1980s led to selfexamination by the university and a reevaluation of its "duties to society." A number of questions arose. Could the university function-supposedly "educating students"while closing its eyes to the sociopolitical disorders in the society, because to do otherwise was to become "political"? Or should it speak out on these issues, because they inhibited the university from functioning? Could the university exercise academic freedom in an environment where freedom of speech, the press, religion, assembly, and association were being systematically repressed and denied? Since the denial of these basic freedoms and civil liberties was connected to authoritarian, personal rule in the society, how could the university conduct research and train students to be independent, critical thinkers in such a repressive envi- ronment?

Rejecting silent partnership in the anarchy and violence by not speaking out, the faculty contended, siding with Jaroslav Pelikan - that as "(a) modern society is unthinkable without the university," not speaking out would do irreparable damage to the society. They further contended that the university is much more than a "knowledge factory," it represents society's collective conscience, and is the guardian of public values, ethics and morality. They agreed with Jose Oretega y Gasset that the university has "responsibility for nourishing and guiding the public soul," and that it must "assert itself as major 'spiritual power,' higher than the press, standing for serenity in the midst of frenzy, for seriousness and the grasp of intellect in the face of frivolity and unashamed stupidity." It wasn't just a sea of "frivolity and unashamed stupidity" in which Liberia was drowning, it was also its slide into anarchy and the violence directed at institutions and those who dared to point out that the whole society was in danger of disintegration, and the possible demise of the state that compelled the university to speak out.

\section{The challenge in 1991 was how to re- open the university-with hardly any resources-in the midst of a war and a fractured society.}

The university, therefore, took an activist role on issues such as: rule of law; democratic governance; self-sustainable, people-centered development; violation and abuse of fundamental human rights; corruption and mismanagement; and social justice. Its open criticism of the Doe regime on these issues led to a brutal raid on and temporary closure of the university on August 22, 1984.

The challenge in 1991 was how to reopen the university — with hardly any resources - in the midst of a war and a fractured society. Reopening the institution was to serve two critical purposes: (1) to make it an instrument for ending the war-since many of the 60,000 combatants were college students who would return to the university to continue their studies-and (2) to begin Liberia's human and institution capacity-building for postwar reconstruction by quickly replenishing the massive brain drain—even as the war raged on.

After cleanup and renovation of a few bombed buildings for makeshift laboratories and classrooms, classes resumed in March 1992, with 4,000 students. A quarter of the enrollment consisted of former combatants, who laid 
down their arms to return to their studies. Trauma-healing workshops were conducted to prepare the entire university community for resumption of classes. We planned a trimester academic year, in which one-third of total enrollment would be engaged in the countryside in any given trimester. The country was divided into zones. For example, agriculture students would work with farmers in the target zone, learning from them and teaching new techniques of modern agriculture. Engineering students would design and construct nonmechanical irrigation systems, sink wells for safe drinking water, and build local houses. Business students would help farmers in setting up bookkeeping to determine their profits and losses, as well as how best to market their produce. Medical students would inoculate everyone against communicable diseases. Education students would conduct mass literacy programs so that, by the end of the trimester, everyone in the target zone would be literate. Pharmacy, botany, and chemistry students would team up with herbalists to study the chemical properties of herbs used in treating diseases in order to produce new drugs. All students would participate in food production and mass literacy.

The following were to be achieved in three to five years: (1) make the university a catalyst for transforming Liberiathe entire society becoming its laboratories/classrooms;

(2) empower students to create their own social knowledge and actively participate in defining and creating their future; (3) make Liberia self-sufficient in food production; (4) wipe out illiteracy; and (5) improve the quality of life of the people.

The program could not be implemented due to the war. By April 1996, enrollment was 5,250, when new factional fighting broke out and the university was looted of all equipment and furniture. It is attempting to rehabilitate itself again - with faculty and students scattered across West Africa.

The University of Liberia's case is not entirely unique, as other universities in Africa, and Central and Eastern Europe have been similarly affected. Yet there is no outrage from the academic community about the plight of these institutions and the societies they serve. If inaction is the result of lack of information, then an alert network system needs to be established that would sound an alarm when a university is threatened or comes under attack. Following breakdown of a university, a consortium of universities in the developed world could be organized to work with foundations and donor governments for its restoration. Since the university is so vital to modern society - particularly its library-it needs to be treated as a museum to be protected by UNESCO, and an international convention should be drawn up for its protection.

\section{A Southeast Asian Initiative in Higher Education SEAMEO-RIHED}

\section{Tong-In Wongsothorn}

Tong-In Wongsothorn is director of RIHED. Address: 5th floor, Ministry of University Affairs Building, 328 Sri Ayutthaya Rd., Bangkok 10400, Thailand. Fax: 662-644-5421.

WHAT IS SEAMEO-RIHED?

7 he history of RIHED dates back to 1959 when the 1 Regional Institute of Higher Education and Development (RIHED) was conceived jointly by UNESCO and the International Association of Universities (IAU), in collaboration with the Ford Foundation. It was not officially founded, however, until 1970, with seven member statesnamely, Cambodia, Indonesia, Laos, Malaysia, Singapore, Thailand, and Vietnam. In 1985 RIHED became inactive due to some of the member countries being unable to participate fully and the decision was then taken to reconstitute RIHED under the SEAMEO umbrella.

The Southeast Asian Ministers of Education Organization (SEAMEO) was established in 1965 in order to hasten the development of the region through regional cooperation in education, science, and culture. In 1993 RIHED, now based in Bangkok, Thailand, became the 12th SEAMEO center, with the mission to promote cooperation for the development of higher education in the region. The original acronym RIHED-from the period when it functioned as a regional institute in Singaporewas retained; however, it is now known as the Regional Centre for Higher Education and Development.

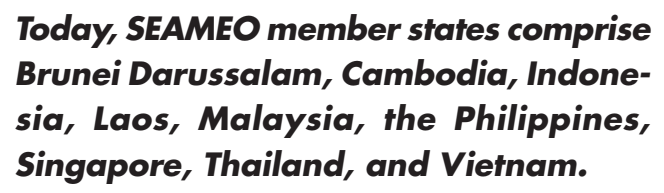

Today, SEAMEO member states comprise Brunei Darussalam, Cambodia, Indonesia, Laos, Malaysia, the Philippines, Singapore, Thailand, and Vietnam. SEAMEO's associate member countries are: Australia, Canada, France, Germany, the Netherlands, and New Zealand.

What ARE THE ACtivities of THE SEAMEO-RIHED? To fulfill its mission RIHED's functions focus on training, research, information dissemination, and the promotion of 